\title{
General repression of enhanson activity by the adenovirus-2 E1A proteins
}

\author{
Cécile Rochette-Egly, Catherine Fromental, and Pierre Chambon \\ Laboratoire de Génétique Moléculaire des Eucaryotes du Centre National de la Recherche Scientifique, Unité 184 de Biologie \\ Moléculaire et de Génie Génétique de l'Institut de la Santé et de la Recherche Médicale, Institut de Chimie Biologique, \\ Faculté de Médécine, 67085 Strasbourg Cédex France
}

It has been shown previously that the adenovirus 2 (Ad2) E1A proteins repress activation of transcription by the SV40, polyomavirus and immunoglobulin gene enhancers. Here, we demonstrate that the repression of the SV40 enhancer is not specifically mediated by one of its constituent enhansons and/or proto-enhancers, but that each is subject to repression individually. This inhibitory effect of the E1A proteins is also observed with the AP-1 factor-binding enhansons from the polyomavirus and human metallothionein enhancers, and the MHC class I gene $\mathrm{H}-2 \mathrm{~K}^{\mathrm{b}}$ enhanson, which binds the KBF1/H2TF1/TC-IIB protein. Repression by the E1A gene products may, in fact, extend to all enhancer trans-activators, because the transcriptional activities of nuclear receptors (e.g., the estrogen and glucocorticoid receptors), of the yeast enhancer factor GAL4 expressed in HeLa cells, and of chimeric trans-activators (such as GAL-VP16) are all similarly inhibited. The E1A protein domains 2 and 3 , including the acidic amino acid stretch that has been shown previously to be necessary for E1A-mediated trans-activation, are not required for repression. These results indicate that the amino-terminal region of the protein, which contains domain 1, plays a crucial role in repression, possibly by interfering in the transcriptional activation process at a step common to all trans-acting enhancer factors.

[Key Words: E1A; transcription; repression; enhancer activity]

Received September 22, 1989; revised version accepted November 1, 1989.

Differential splicing of the primary transcript of the human adenovirus-2 (Ad2) E1A early gene yields two overlapping mRNAs (see Fig. 1; Perricaudet et al. 1979). These $12 S$ and $13 S$ mRNAs encode two nuclear phosphoproteins, 243 and 289 amino acids in length (243R and 289R), respectively (Graham 1984), which share identical amino and carboxyl termini and differ in their primary sequence only by the presence of 46 amino acids that are unique to the $289 \mathrm{R}$ protein (Fig. 1).

The oncogenic E1A proteins have a pleiotropic effect on the regulation of eukaryotic gene transcription (for review, see Sassone-Corsi 1985; Berk 1986a,b; Jones et al. 1988). The $289 \mathrm{R}$ protein and, to a lesser extent, the 243R protein (Leff et al. 1984), activate transcription of the other adenovirus early genes and of a number of cellular genes (for reviews, see Berk 1986a,b; Grand 1987). On the other hand, the E1A proteins repress transcription from promoters that are linked to different viral and cellular enhancers, such as the SV40 enhancer (Borrelli et al. 1984; Velcich and Ziff 1985), the polyomavirus enhancer (Borrelli et al. 1984; Velcich et al. 1986), the IgH enhancer (Hen et al. 1985), the insulin enhancer (Stein and Ziff 1987), and the cytochrome P-450 gene enhancer (Sogawa et al. 1989). It was concluded from these studies that the enhancer, itself, was probably the target for the negative regulation by the E1A products. Furthermore, it

C. Rochette-Egly and C. Fromental should be considered equal first authors. was shown that the ElA proteins repress the transcription of several cellular genes (K.A. Webster et al. 1988; Timmers et al. 1988, 1989; Young et al. 1989), but the target within the promoter region of these genes was not identified. The expression of class I major histocompatibility complex (MHC) antigens is also inhibited by the E1A proteins (Friedman and Ricciardi 1988), but in this case, the inhibition may not be only transcriptional (Vaessen et al. 1987; Meijer et al. 1989).

The various E1A functions have been mapped to three protein domains that are conserved among adenoviruses (see Fig. 1). One of these domains, domain 3 (amino acids $140-189$ ), which is specific to the $289 \mathrm{R}$ protein, is sufficient for E1A-mediated transcriptional trans-activation (Lillie et al. 1986, 1987; Moran et al. 1986; M. Green et al. 1988; Jelsma et al. 1988; Fahnestock and Lewis 1989). On the other hand, domains 1 (amino acids $41-79$ ) and 2 (amino acids 121-139), which are common to both the $289 \mathrm{R}$ and $243 \mathrm{R}$ proteins, appear to be required for both repression and/or oncogenic transformation but not for trans-activation, which suggested that transcriptional repression was important for transformation (Lillie et al. 1986, 1987; Schneider et al. 1987; Whyte et al. 1989). However, in other reports, enhancer repression could not be critically mapped to domains 1 and 2 (Kuppuswamy and Chinnadurai 1987; Velcich and Ziff 1988).

It is not known how transcription is activated by the E1A 289 R protein. It does not appear to bind directly to DNA elements of the activated promoters (Ferguson et al. 1985); rather, it increases transcription by modifying 


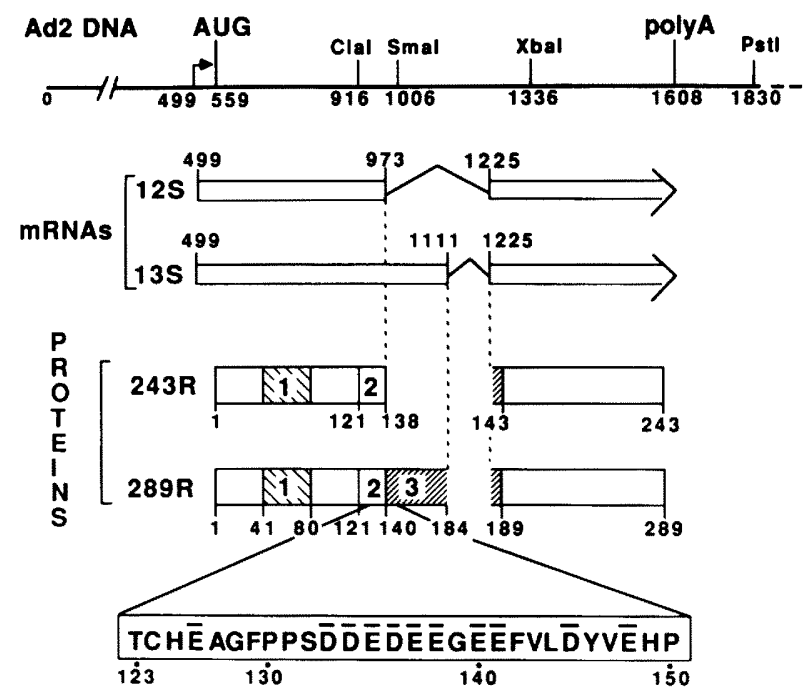

Functions of E1A domains

\begin{tabular}{llll} 
& \multicolumn{3}{c}{ E1A Domains } \\
\cline { 2 - 3 } & (1) & (2) & (3) \\
TRANSCRIPTIONAL ACTIVATION (a) & - & - & + \\
TRANSCRIPTIONAL REPRESSION (b) & + & + & - \\
TRANSFORMATICN (c) & + & + & - \\
& & \\
Region involved in binding to cellular proteins \\
300K PROTEIN BINDING (d) & AA $1-76$ \\
107K PROTEIN BINDING (d) & AA $121-127$ \\
P105-RB PROTEIN BINDING (d) & AA $30-60,121.127$
\end{tabular}

Figure 1. Schematic representation of the differentially spliced mRNA products of the ElA region. Positions of the transcription start site (499), AUG (559), and polyadenylation sites (1608), as well as selected restriction endonuclease cleavage sites, are indicated. Numbers indicate base pairs, beginning at the left end of the $\mathrm{Ad} 2$ genome. Arrows indicate the direction of transcription of the mRNAs. Open boxes indicate the exons of the $13 \mathrm{~S}$ and $12 \mathrm{~S}$ mRNA; carets indicate the intron transcripts removed by splicing. The nucleotide positions of the splicing sites are indicated above the exons. The $243 \mathrm{R}$ and $289 \mathrm{R}$ proteins are shown with the location of their three conserved structural domains 1, 2, and 3. Region 1 spans amino acids 41-79; region 2 spans amino acids 121-139; region 3 , unique to the 289-amino-acid protein, spans amino acids $140-188$. The amino acid sequence of acidic region 123-150 deleted in the pElASVA recombinant is shown below. Negatively charged amino acids are overlined. (a) Lillie et al. $(1986,1987)$; Moran et al. (1986); Schneider et al. 1987; M. Green et al. (1988); Jelsma et al. (1988). (b) Lillie et al. (1986, 1987); Kuppuswamy and Chinnadurai 1987; Schneider et al. 1987. (c) Moran et al. (1986); Kuppuswamy and Chinnadurai (1987); Whyte et al. (1988, 1989). (d) Egan et al. (1988); Whyte et al. $(1988,1989)$.

the activity of cellular transcriptional factors (Berk 1986a,b; Hoeffler et al. 1988; Bagchi et al. 1989; Hardy et al. 1989; Jansen-Durr et al. 1989, and references therein). How the 289R and 243R proteins repress the function of viral and cellular enhancers is also not known. Since our initial report describing the inhibition of the activity of the SV40 enhancer by both of these proteins (Borrelli et al. 1984), it has become apparent that this enhancer is not a simple target. Rather, it is composed of multiple functional elements (enhansons) that act synergistically to stimulate transcription from an associated promoter (Herr and Clarke 1986; Zenke et al. 1986; Nomiyama et al. 1987; Ondek et al. 1987, 1988; Schirm et al. 1987; Fromental et al. 1988; Kanno et al. 1989). These enhansons (Fig. 2) were categorized in three classes according to their proto-enhancer activity, that is, their ability to generate enhancer activity when oligomerized independently (Fromental et al. 1988). Class A enhansons (e.g., GT-IIC, Sph) exhibit proto-enhancer activity either as a tandem repeat or when associated with a class B enhanson; class B enhansons (e.g., GT-I) have no proto-enhancer activity alone, even as a tandem repeat, but can cooperate with a class $\mathrm{A}$ enhanson to form a proto-enhancer (e.g., GT-IIC + GT-I); class C enhansons (e.g., TC-II, octamer) exhibit a proto-enhancer activity independently. In addition, the SV40 enhancer contains two elements that have been less thoroughly characterized-the P motif (Zenke et al. 1986) and the purine box, which is active only in lymphoid cells (Pettersson and Schaffner 1987). Each enhanson binds at least one trans-acting factor, which mediates its stimulatory effect. TEF-2 interacts with the GT-I enhanson (Xiao et al. 1987a, Davidson et al. 1988); TEF-1 binds specifically to the GT-IIC and Sph-II and Sph-I enhansons, even though their sequences are apparently unrelated (Xiao et al. 1987b; Davidson et al. 1988); the TC-IIA/NF-kB-like and TC-IIB/KBF1/H2TFl-like proteins bind to the TC-II enhanson /these two latter proteins also bind to the $\kappa \mathrm{B}$ proto-enhancer from the $\kappa$ light chain enhancer and the $\mathrm{H}-2 \mathrm{~K}^{\mathrm{b}}$ proto-enhancer from MHC $\mathrm{H}-2 \mathrm{~K}^{\mathrm{b}}$ gene promoter) (Sen and Baltimore 1986; Kanno et al. 1989, and references therein; Macchi et al. 1989|; the octameric proto-enhancer, whose activity is mostly restricted to lymphoid cells (Davidson et al. 1986; Fromental et al. 1988, Fromental 1989), binds several ubiquitous and lymphoid cell-specific octamerbinding proteins (Fletcher et al. 1987; Gerster et al. 1987). Finally, the protein AP-1 binds to the P element (Angel et al. 1987; K.A.W. Lee et al. 1987). Furthermore, it has been reported that the activity of the trans-acting factors AP-1 (Angel et al. 1987; Chiu et al. 1987; W. Lee et al. 1987), TC-IIA (NF-kB-like) and TC-IIB (KBF1/ H2TF1-like) (Kanno et al. 1989, and references therein; Macchi et al. 1989) can be stimulated in HeLa cells by treatment with the phorbol ester TPA |12-O-tetradecanoylphorbol-13-acetate).

To investigate further the molecular mechanisms underlying the repression of the SV40 enhancer by the E1A proteins, we have now studied the repression of the enhancer activity of the different tetramerized SV40 protoenhancers. We demonstrate here that the activity of all SV40 proto-enhancers is inhibited, indicating that ElA repression does not involve an interaction with a specific enhanson or its cognate trans-acting factor. Furthermore, the magnitude of the repression of TPA-responsive enhansons is unchanged in TPA-treated cells. We also present evidence that this E1A protein inhibi- 


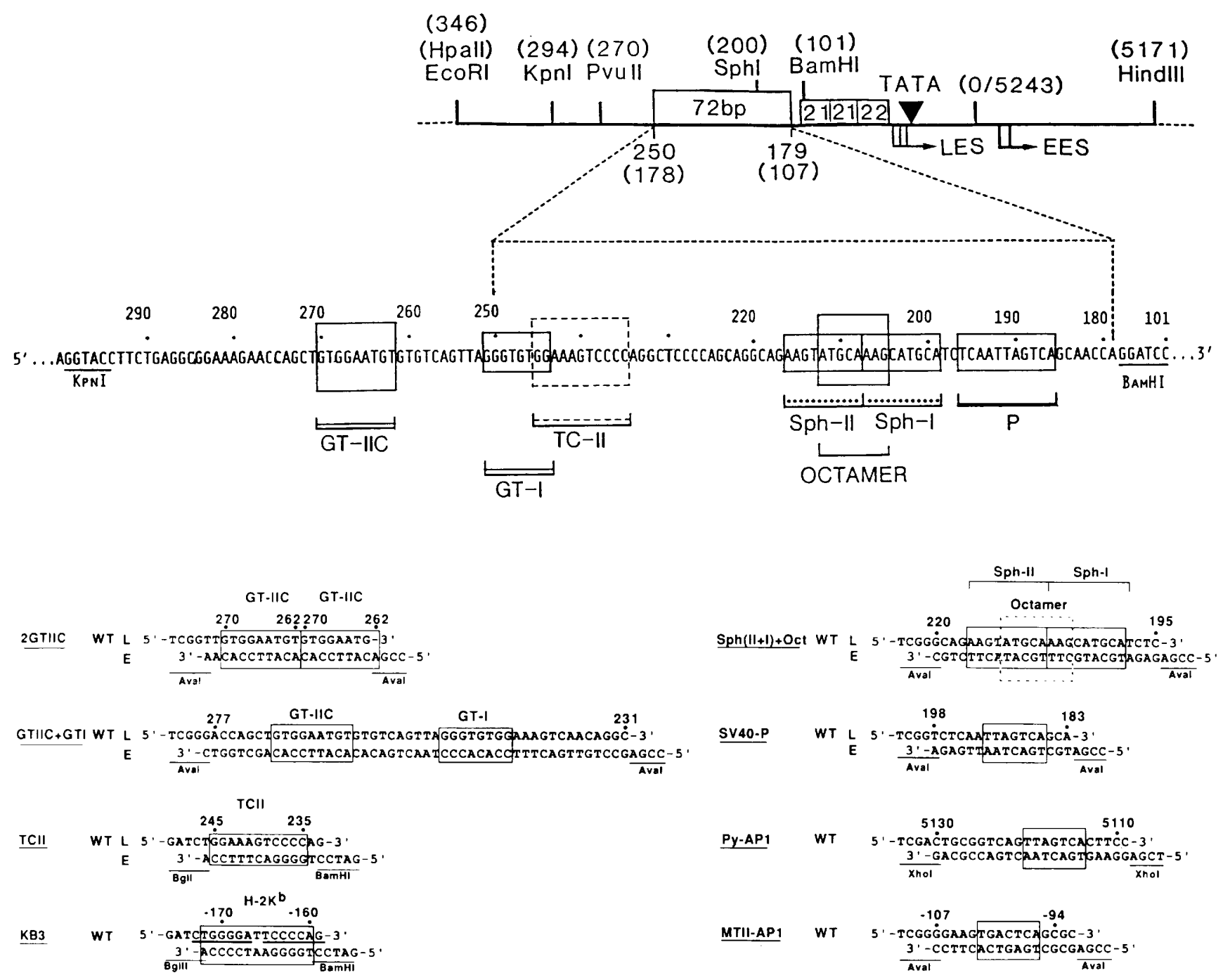

Figure 2. Organization of the SV40 promoter and structure of the different enhansons. (Top) The structure of the SV40 early promoter (Zenke et al. 1986), containing only one copy of the 72-bp sequence. The positions of the essential elements of the promoter, the TATA box, the 21-bp repeat element (21,21, and 22), and the 72-bp enhancer element, are indicated, along with the coordinates of several restriction enzyme recognition sites. EES and LES indicate the positions of the early-early and late-early mRNA start sites, respectively. (Middle) The sequence of the late coding strand of the 72-bp element (indicated by vertical broken lines) and the $5^{\prime}$ flanking sequences. The different enhansons are boxed. (Bottom) The structure of the units containing the different enhansons (boxed) that were tetramerized and tested in this study for enhancer activity. For the SV40 enhansons, E and L designate the early and late SV40-coding strands, respectively. KB3 corresponds to a proto-enhancer element present in the promoter region of $\mathrm{MHC}$ class I $\mathrm{H}-2 \mathrm{~K}^{\mathrm{b}}$ gene (for references, see Kanno et al. 1989); Py-AP1 and MTII-AP1 correspond to AP1 factor-binding enhansons present in the polyomavirus enhancer (Imler et al. 1988, and references therein) and the human metallothionein IIA gene (W. Lee et al. 1987), respectively.

tory action can be extended to class $\mathrm{D}$ enhansons which, as monomers, possess enhancer activity independently (see Fromental et al. 1988), such as monomers of steroid hormone responsive elements that are activated by the corresponding nuclear receptor in the presence of the cognate hormone, and even to yeast upstream activator sequences (UASs), such as $\mathrm{UAS}_{\mathrm{G}}$, whose activity is mediated by the GAL4 trans-activator. Finally, we show that the acidic amino acid stretch that is located across the border of domains 2 and 3 of the E1A proteins is not important for enhancer repression, which indicates that the amino-terminal region of the E1A proteins that contains domain 1 plays a crucial role in enhancer repression.

\section{Results}

\section{Experimental design}

The inhibitory action of the E1A gene products on enhancer activity was studied using transient transfection assays with human HeLa cells, mouse MPC11 plasmo- 
cytoma B cells, $\mathrm{LMTK}^{-}$fibroblasts, and undifferentiated [F9(ND)] or retinoic acid-differentiated [F9(D)] F9 embryonal carcinoma cells. The reporter recombinants containing the various enhansons or proto-enhancers inserted in the promoter region of rabbit $\beta$-globin gene at either -109 (pG1 series) or -425 (pG2 series) (Fromental et al. 1988; N. Webster et al. 1988a,b; Kanno et al. 1989) were transfected together with the recombinant pE1ASV, which expresses both the $12 \mathrm{~S}$ and $13 \mathrm{~S}$ E1A mRNAs (Sassone-Corsi et al. 1983), and enhancer activity was determined by quantitative $S 1$ nuclease analysis of RNA transcribed from the $\beta$-globin gene promoter (Glob+1 signal; see Figs. 3-6). A recombinant, pA56, containing the SV40 early promoter, but deleted for the enhancer sequence from coordinates 107-271 (see Fig. 2; Zenke et al. 1986), was cotransfected as a reference plasmid to correct for variations in transfection efficiency, as described previously (Fromental et al. 1988) (EES signal; see Figs. 3-6). The results were expressed as a percentage of transcription from the globin cap site $(\mathrm{Glob}+1)$, with $100 \%$ represented by either pG1B or pG2B, which contain the SV40 enhancer (with one copy of the 72-bp sequence; Fig. 2) inserted at position -109 (pG1B) or -425 (pG2B) of the $\beta$-globin gene promoter.

Alternatively, the results were expressed relative to pG1 or pG2 as the fold stimulation of transcription induced by the enhancer element. Control experiments were performed in all cases with the recombinant pE1A- (Sassone-Corsi et al. 1983), which contains the E1A promoter but not the ElA-coding sequence, to check that the observed repression was not attributable to competition between the promoters of the cotransfected recombinants (see, e.g., Figs. 4A and 5). Note that transcription from the isolated globin promoter in pG1 and pG2 was never affected by the ElA gene products (see Figs. 4A and 5; data not shown).

\section{Individual SV40 proto-enhancers and related proto- enhancers are all repressed by E1A products in different cell types}

As expected from a previous report (Borrelli et al. 1984), the activity of the SV40 enhancer in pG1B /where it causes a 400 -fold increase in transcription) was progressively repressed when increasing amounts of pE1ASV were cotransfected into HeLa cells (Fig. 3A), whereas transcription from the reference plasmid pA56 was unaffected. The effect of the E1A gene products on the activity of the different SV40 enhansons was then studied using a pG1-based reporter gene containing tetramers of the various proto-enhancers previously characterized (see Figs. 2 and 3; Fromental et al. 1988; Kanno et al. 1989). The recombinants, 2GTIIC, GTIIC + GTI,TCII, Sph(II + I) (Fig. 3B-E), and SV40-P (Table 1) contain, in pGl, the tetramers of the respective synthetic oligonucleotides displayed in Figure 2 [note that in the case of $\mathrm{Sph}(\mathrm{II}+\mathrm{I})$, the wild-type octamer enhanson, which is also present, is known to be inactive in HeLa cells (Davidson et al. 1986; Fromental et al. 1988/]. In all cases, similar profiles of repression by the E1A products were observed (Fig. 3). A summary of the reslts obtained with $1 \mu \mathrm{g}$ of cotransfected pE1ASV is given in Table 1, where the extent of repression is indicated by the bracketed

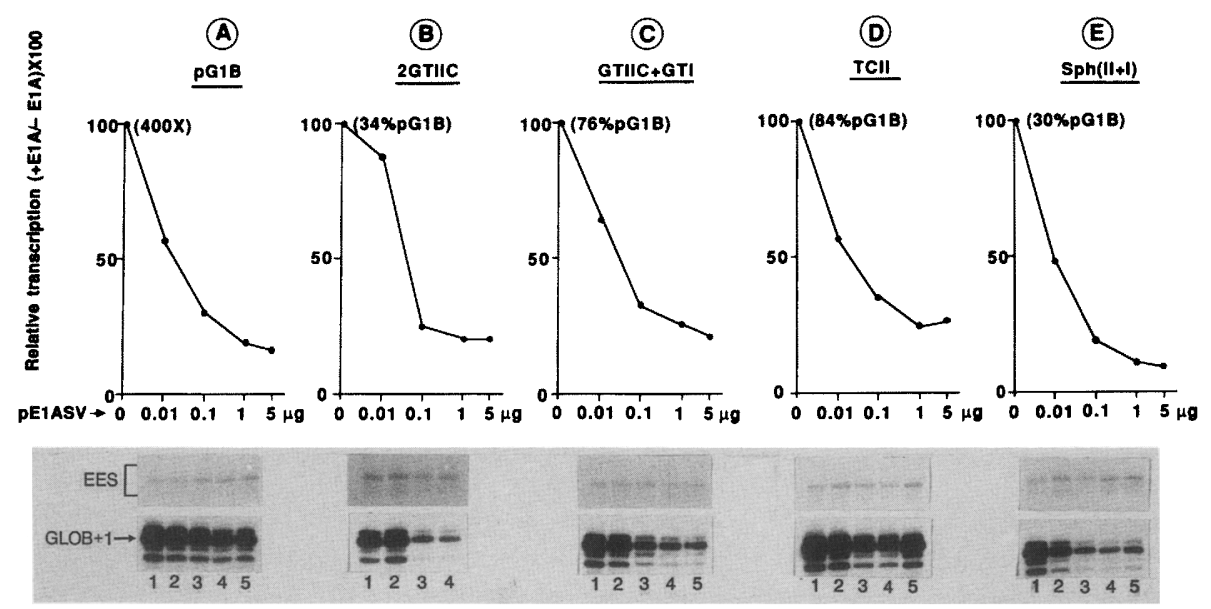

Figure 3. Repression by E1A proteins of the SV40 proto-enhancers cloned in pG1. HeLa cells were cotransfected with a constant amount $(2 \mu \mathrm{g})$ of pG1 recombinant containing the tetramerized proto-enhancers, as indicated, the reference plasmid pA56 (10 $\mu \mathrm{g})$, and varying amounts of the pE1ASV plasmid $(0.01-5 \mu \mathrm{g})$. For each $\mathrm{pG} 1$ recombinant, the results are represented as the ratio of $\beta$-globin transcription in the presence and absence of pE1ASV. At the top of each curve, the value in parentheses indicates the activity of each proto-enhancer as a percentage of the activity of the total SV40 enhancer in pGIB. In the case of pG1B, the value in parentheses $(400 \times)$ indicates the amount of stimulation, compared with the enhancerless pG1 recombinant. The corresponding quantitative S1 nuclease analysis of cytoplasmic RNA is presented below. Protected fragments of $130-137$ and 60 nucleotides correspond to mRNA initiated at the SV40 promoter early-early (EES of the reference plasmid pA56) and $\beta$-globin promoter $(\mathrm{Glob}+1)$ start sites, respectively. Repression by E1A proteins was tested on the activity of pGlB $(A)$ and the proto-enhancers 2 GT-IIC $(B), \mathrm{GT}$-IIC + GT-I $(C)$, $\mathrm{TC}-\mathrm{II}(D)$, and $\mathrm{Sph}(\mathrm{II}+\mathrm{I})(E)$. In the case of the proto-enhancer $2 \mathrm{GT}$-IIC, the autoradiograph for $5 \mu \mathrm{g}$ pE1ASV is not shown. Transcription from the internal control of pA56 was not affected at any pElASV concentration. 


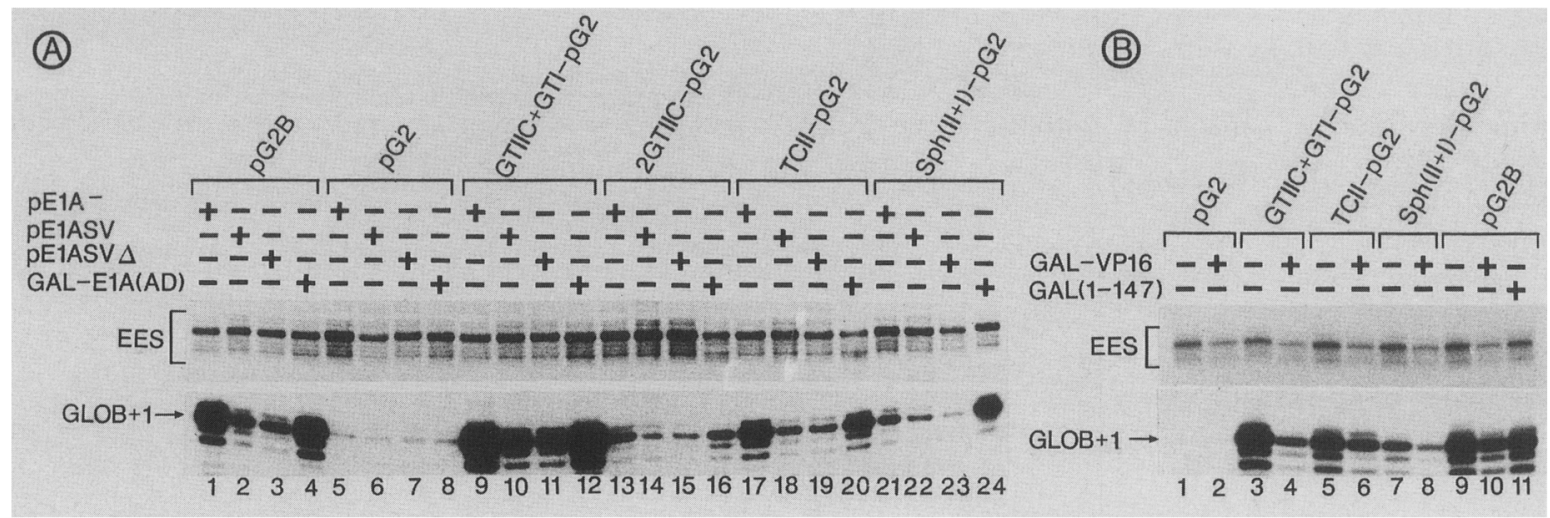

Figure 4. Repression of the SV40 proto-enhancers cloned in pG2 by E1A proteins and their derivatives $(A)$ or GAL-VP16 $(B)$. $(A)$ S1 nuclease analysis of cytoplasmic RNA extracted from HeLa cells cotransfected with $2 \mu \mathrm{g}$ of pG2, or pG 2 recombinants containing either the 72-bp sequence of SV40 enhancer (lanes 1-4) or the tetramerized SV40 proto-enhancers [GT-IIC + GT-I (lanes 9-12); 2GT-IIC (lanes 13-16); TC-II (lanes 17-20) and Sph(II +I) (lanes 21-24)] in the absence $(-)$ or in the presence $(+)$ of pE1A- $(1 \mu \mathrm{g})$, pE1ASV $(1 \mu \mathrm{g}), \mathrm{pE} 1 \mathrm{ASV} \Delta(1 \mu \mathrm{g})$ or GAL-E1A (AD) $(5 \mu \mathrm{g})$, as indicated. Transcription from the enhancerless SV40 early promoter in pA56 (EES signal) and from the enhancerless $\beta$-globin promoter in pG2 (lanes $5-8$ ) was not affected by E1A proteins or their derivatives. EES and Glob +1 are as described in the legend to Fig. 3. $(B)$ The experimental procedure is as described in $A$, except that each pG2 recombinant was cotransfected with $(+)$ or without $|-| 2 \mu \mathrm{g}$ of GAL-VP16. As a control and to check that the DBD (1-147) of GAL4 does not affect the $\beta$-globin transcription, GAL(1-147) was cotransfected with pG2B (lane 11). Note that transcription from the enhancerless SV40 early promoter present in the internal control pA56 (EES signal, lanes 2, 4, 6, 8, and 10), but not that from the enhancerless $\beta$-globin promoter in pG2 (lane 2; data not shown), was slightly repressed by GAL-VP16.

numbers. Because of tetramerized P element of the SV40 enhancer has no enhancer activity in HeLa cells (Table 1; Fromental 1989|, we also tested the effect of the E1A gene products on two related tetramerized enhansons, the AP-1/PEA1-binding site (Imler et al. 1988, and references therein) of the polyomavirus enhancer, which is also known to be repressed by the E1A proteins (Borrelli et al. 1984; Velcich et al. 1986), and the 'upstream' AP-1-binding site of the human metallothionein IIA gene that is important for transcription in vivo (W. Lee et al. 1987) (see Py-AP1 and MTII-AP1 in Fig. 2). The enhancer activity of these tetramerized enhansons was also repressed by the E1A products (Table 1).

The stimulatory activity of the various SV40 tetra- merized proto-enhancers was similarly inhibited by the E1A gene products when they were inserted 'at a distance' from the globin gene promoter in the pG2 recombinant (Fig. 4A; Table 2). Therefore, we conclude from the above results that the activity of all of the SV40 enhansons that are active in HeLa cells is repressed by the E1A proteins.

The possible repression of the SV40 cell-type-specific octamer proto-enhancer, which is active in lymphoid B cells (Davidson et al. 1986; Nomiyama et al. 1987; Fromental et al. 1988; Tanaka et al. 1988), was studied in MPC11 cells using a pGl-based recombinant containing a tetramer of the synthetic oligonucleotide $\mathrm{Sph}(\mathrm{II}+\mathrm{I})+$ OCT M2 in which the Sph enhansons, but not the

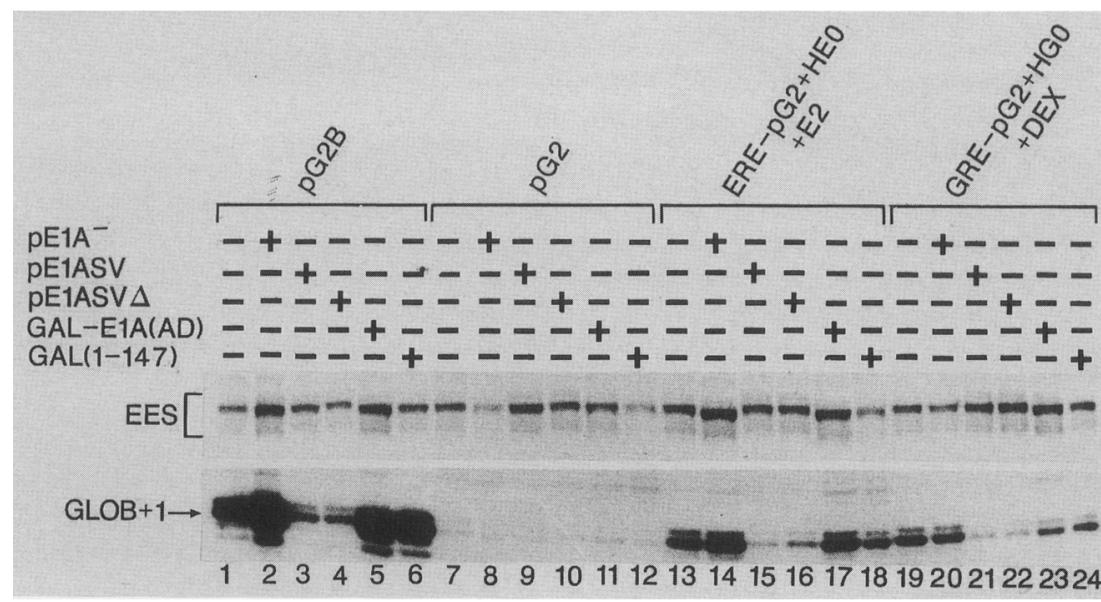

Figure 5. Repression by E1A proteins of activation of transcription by the estrogen and glucocorticoid receptors. $S 1$ nuclease analysis was performed with cytoplasmic RNA extracted from HeLa cells transfected with $2 \mu \mathrm{g}$ of the pG2 recombinants (as indicated) in the absence $(-)$ or in the presence (+) of GAL/1147) $(5 \mu \mathrm{g})$ and the different pElASV derivatives, pE1A- $(1 \mu \mathrm{g})$, pE1ASV $(1 \mu \mathrm{g})$, pE1ASV $\Delta$ $(1 \mu \mathrm{g})$, and GAL-E1A(AD) $(5 \mu \mathrm{g})$, as indicated. In each case, the ERE-pG2 estrogen reporter gene was cotransfected with the human estrogen receptor expression vector HEO $(0.5$ $\mu \mathrm{g})$ in the presence of $\mathrm{E} 2\left(10^{-8} \mathrm{M}\right)$, whereas the GRE-pG2 glucocorticoid reporter gene recombinant was cotransfected with the glucocorticoid receptor expression vector HGO $(1 \mu \mathrm{g})$ in the presence of dexamethasone (DEX, $10^{-7} \mathrm{M}$ ). EES and Glob +1 are as described in the legend to Fig. 3. 
Table 1. Repression by E1A proteins of the activity of the different proto-enhancers cloned in $p G 1$, in the absence or in the presence of the tumor promoter TPA

\begin{tabular}{|c|c|c|c|c|}
\hline \multirow[b]{2}{*}{ Enhancer } & \multicolumn{4}{|c|}{ Enhancer activity (relative to pGlB) } \\
\hline & Control & $+\mathrm{E} 1 \mathrm{~A}$ & + TPA & $\begin{array}{l}\text { TPA + } \\
\text { E1A }\end{array}$ \\
\hline $\mathrm{pG} 1 \mathrm{~B}$ & 100 & $19[81]$ & 135 & $29[79]$ \\
\hline 2GTIIC & 34 & $6[82]$ & 34 & $6[82]$ \\
\hline GTIIC + GTI & 76 & $19[75]$ & 76 & $19[75]$ \\
\hline TCII & 84 & $20[75]$ & 160 & $38[76]$ \\
\hline $\operatorname{Sph}(I I+I)$ & 30 & $4[87]$ & 30 & $4[87]$ \\
\hline SV40-P & 0 & 0 & 0 & 0 \\
\hline $\mathrm{Py}-\mathrm{AP} 1$ & 13 & $5[63]$ & 174 & $60[66]$ \\
\hline MTIIA-AP1 & 18 & $3[83]$ & 76 & $40[47]$ \\
\hline KB3 & 4 & $2[50]$ & 56 & $22[61]$ \\
\hline
\end{tabular}

The enhancer activity of each recombinant $(2 \mu \mathrm{g})$, cotransfected in the presence or absence of TPA (100 ng/ml) with or without pE1ASV $(1 \mu \mathrm{g}$, +E1A), was determined by densitometric scanning of several exposures of autoradiograms similar to those shown in Fig. 3 from at least three different experiments. For each proto-enhancer, the average values $( \pm 5 \%)$ correspond to the relative transcription from the globin start site (Glob +1 ), taking pG1B as $100 \%$. Numbers in brackets indicate the percentage of enhancer activity inhibition by E1A proteins.

octamer enhanson, are mutated [Fromental et al. (1988); note that in the reciprocal oligonucleotide Sph(II + I) + OCT M1, the octamer enhanson, but not the Sph enhansons, is mutated; see Table 3]. The octamer enhanson [Sph(II + I) + OCT M2] was repressed in MPC11 cells to the same extent as the whole SV40 enhancer $(\mathrm{pG} 1 \mathrm{~B})$ and the TC-II enhanson, which is also known to be active in lymphoid B cells (Kanno et al. 1989). As expected from our previous reports (Davidson et al. 1988; Fromental et al. 1988), the GT-II and GT-I enhansons were inactive in MPC11 cells. We note that in MPC11 cells, the SV40 'enhancerless' pA56 recombinant, which still contains the lymphoid cell-specific purine box enhancer element (Pettersson and Schaffner 1987), was repressed by the E1A proteins (data not shown), which suggests that this latter enhanson may also be subject to E1A repression.

Finally, the inhibitory effect of the E1A products on the activity of the various SV40 enhansons was studied in the nonlymphoid mouse cell line LMTK ${ }^{-}$(Table 3). A repression was clearly seen in all cases, although the magnitude of the inhibition (with $1 \mu \mathrm{g}$ of transfected pElASV) was lower than in HeLa or MPC11 cells, indicating that the E1A repression of the SV40 enhancer activity is not cell-specific, a conclusion that was further supported by the observation that the activity of the

Table 2. Repression by E1A proteins or by GAL-VP16 of the activity of the SV40 proto-enhancers cloned in pG2 and comparison with the repression of the activity of the human $E R, G R$, and GAL4 yeast activator

\begin{tabular}{lrrc}
\hline & & Enhancer activity (fold stimulation) \\
\cline { 2 - 4 } Enhancer & Control & + E1A & $14[86]$ \\
pG2B & 100 & 1 & $46[54]$ \\
pG2 & 1 & $3[85]$ & 1 \\
2GTIIC-pG2 & 20 & $24[85]$ & ND \\
GTIIC + GTI-pG2 & 160 & $11[83]$ & $16[90]$ \\
TCII-pG2 & 64 & $5[80]$ & $30[53]$ \\
Sph(II + I)-pG2 & 26 & $3[90]$ & $6[75]$ \\
ERE-pG2 + HEO & 30 & $2[92]$ & ND \\
GRE-pG2 + HGO & 25 & $4[89]$ & ND \\
UAS-pG2 + GAL4 & 37 & $160[85]$ & ND \\
UAS-pG2 + GAL-VP16 & 1055 & $4[91]$ & ND \\
UAS-pG2 + GAL-ER(EF) & 45 & ND \\
\hline
\end{tabular}

Each pG2 recombinant $(2 \mu \mathrm{g})$ was transfected either alone or with pE1ASV $(1 \mu \mathrm{g}$, + E1A) or GAL-VP16 $(2 \mu \mathrm{g})$, as indicated (see also Fig. 4). ERE-pG2 and GRE-pG2 recombinants were transfected with the ER expression vector HEO $(0.5 \mu g)$ and the GR expression vector HGO $(1 \mu \mathrm{g})$, respectively, in the presence of E2 $\left(10^{-8} \mathrm{M}\right)$ or DEX $\left(10^{-7} \mathrm{M}\right)$ (see Fig. 5). UAS-pG2 was cotransfected with GAL4 (the expression vectors of GAL4, $1 \mu \mathrm{g})$, GAL-VP16 $(0.2 \mu \mathrm{g})$, or GAL-ER(EF) $\left(1 \mu \mathrm{g}\right.$; see Fig. 6). In the latter case, E2 $\left(10^{-8} \mathrm{M}\right)$ was added simultaneously. The results obtained (as in Table 1) are expressed as the extent of stimulation of transcription when compared with transcription from the enhancerless globin promoter present in $\mathrm{pG} 2$. Numbers in brackets indicate the percentage of enhancer activity inhibition by E1A proteins or by GAL-VP16. (ND) Not determined. 
Table 3. Repression by E1A proteins of the activity of different proto-enhancers cloned in pG1 after transfection in MPC11 and LMTK- cells

\begin{tabular}{|c|c|c|c|c|}
\hline \multirow[b]{3}{*}{ Enhancer } & \multicolumn{4}{|c|}{ Enhancer activity (relative to pG1B) } \\
\hline & \multicolumn{2}{|c|}{ MPCl1 } & \multicolumn{2}{|c|}{ LMTK $^{-}$} \\
\hline & Control & $+\mathrm{E} 1 \mathrm{~A}$ & Control & $+\mathrm{E} 1 \mathrm{~A}$ \\
\hline pG1B & 100 & $15[85]$ & 100 & $43[57]$ \\
\hline GTIIC + GTI & 0 & 0 & 12 & $5[59]$ \\
\hline 2GTIIC & 0 & 0 & 20 & $13[35]$ \\
\hline TCII & 210 & $39[81]$ & 108 & $64[40]$ \\
\hline $\operatorname{Sph}(\mathrm{II}+\mathrm{I})+\mathrm{OCT} M 1$ & ND & ND & 31 & $16[49]$ \\
\hline $\mathrm{Sph}(\mathrm{II}+\mathrm{I})+\mathrm{OCT} \mathrm{M} 2$ & 115 & $11[90]$ & ND & ND \\
\hline KB3 & 172 & $43[75]$ & ND & ND \\
\hline
\end{tabular}

MPC11 cells were cotransfected with $3 \mu \mathrm{g}$ of the pGl recombinants and $5 \mu \mathrm{g}$ of pE1ASV (+E1A), whereas LMTK ${ }^{-}$cells were cotransfected with $2 \mu \mathrm{g}$ of the pGl recombinants and $1 \mu \mathrm{g}$ of pElASV, as indicated. For each proto-enhancer, the average values $( \pm 10 \%)$ obtained (as in Table 1$)$ correspond to the relative transcription from the globin start site (Glob +1$)$, taking pG1B as $100 \%$. Numbers in brackets indicate the percentage of enhancer inhibition by E1A proteins.

same SV40 enhancer was also repressed in cotransfection experiments carried out in $\mathrm{F} 9(\mathrm{ND})$ and $\mathrm{F} 9(\mathrm{D})$ embryonal carcinoma cells (data not shown).

\section{$A$ variety of enhancer elements are repressed by the E1A proteins}

The promoter region of $\mathrm{MHC}$ class $\mathrm{I} \mathrm{H}-2 \mathrm{~K}^{\mathrm{b}}$ gene contains a proto-enhancer element whose sequence is related to the SV40 TC-II enhanson (Kanno et al. 1989, and references therein). The $\mathrm{H}-2 \mathrm{~K}^{\mathrm{b}}$ proto-enhancer (KB3 in Fig. 2) was tetramerized in pGl, and its activity was studied both in HeLa cells (Table 1), where it was low, and in MPC1 1 cells, where it was much higher (Table 3). In both cases, it was repressed by the E1A products.

A steroid hormone-responsive element belongs to class D enhansons (Fromental et al. 1988), in that it activates transcription as a monomer in the presence of its cognate liganded hormone receptor, which acts as an inducible enhancer factor (for review and references, see Green and Chambon 1988). ERE-pG2 and GRE-pG2, in which a synthetic estrogen-responsive element (ERE) and a synthetic glucocorticoid-responsive element (GRE) were inserted in pG2 at position -425 (see Materials and methods), are reporter genes for the estrogen receptor (ER) and the glucocorticoid receptor (GR). Cotransfection in HeLa cells of the ER expression vector HEO with ERE-pG2, and of the GR expression vector HGO with GRE-pG2, resulted in enhancement of transcription from the $\beta$-globin promoters (Fig. 5 ; Table 2). A strong repression of both the estrogen and glucocorticoid enhancer activity was brought about by cotransfection of $1 \mu \mathrm{g}$ of pE1ASV, but not pE1A- (Fig. 5, lanes 13-15 and 19-21; Table 2).

Like higher eukaryote enhancers, the (UASs) of several yeast promoters are binding sites for trans-activating proteins, such as the yeast transcriptional activator GAL4, which interacts with the $\mathrm{UAS}_{\mathrm{G}}$ element (for reviews, see Struhl 1987; Guarente 1988). Interestingly, GAL4 functions as an enhancer factor in HeLa cells, where it has been shown to efficiently stimulate tran- scription from several higher eukaryote promoters to which the UAS ${ }_{\mathrm{G}}$ element had been added (Kakidani and Ptashne 1988; N. Webster et al. 1988a). In UAS-pG2, the $\mathrm{UAS}_{\mathrm{G}}$ element was inserted at position -425 upstream from the globin gene start site of pG2. Transfection of pE1ASV into HeLa cells, together with UASpG2 and a vector expressing the GAL4 protein (GAL4), resulted in a marked repression of GAL4 trans-activation (Fig. 6, cf. lanes 7 and 8), indicating clearly that the ElA proteins can repress the activity of the yeast transactivator GAL4.

The repression function of the E1A gene products was further tested on two chimeric trans-activators whose

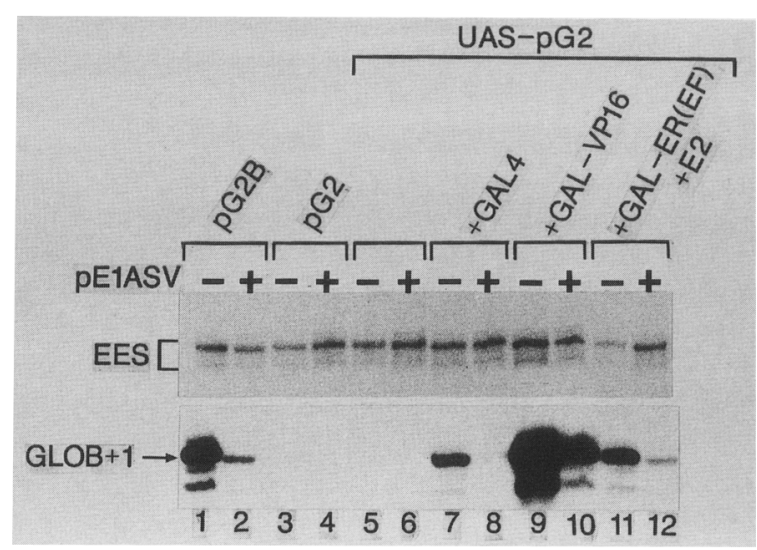

Figure 6. Repression by E1A proteins of the yeast activator GAL4 and the chimeric activators GAL-VP16 and GALER(EF). S1 nuclease analysis was performed with cytoplasmic RNA extracted from HeLa cells transfected with $2 \mu \mathrm{g}$ of the UAS-pG2 reporter gene in the absence (lanes 5 and 6) or in the presence of vectors expressing the trans-activators GAL4 $(1 \mu \mathrm{g}$, lanes 7 and 8), GAL-VP16 $(0.2 \mu \mathrm{g}$, lanes 9 and 10), and GAL$\mathrm{ER}(\mathrm{EF})(1 \mu \mathrm{g}$, lanes 11 and 12$)$, as indicated. The transfections were performed in the absence $(-)$ or in the presence $(+)$ of $1 \mu \mathrm{g}$ pE1ASV, as indicated. E2, $\left(10^{-8} \mathrm{M}\right)$ was added to cells transfected with GAL-ER(EF). EES and Glob +1 are as described in the legend to Fig. 3. 
DNA-binding domains (DBD) correspond to that of GAL4 (amino acids 1-147). In GAL-VP16 (Sadowski et al. 1988; Tora et al. 1989|, the powerful acidic trans-activating domain (amino acids 411-491) of the herpesvirus VP16 protein is associated with GAL4) $1-$ 147|DBD. In GAL-ER(EF), the estradiol (E2)-inducible activating domain present in the ER region (EF), which also contains the hormone-binding domain, is associated with GAL4(1-147)DBD (N. Webster et al. 1988b; Tora et al. 1989). The enhancer activity of both chimeric trans-activators was markedly inhibited in HeLa cells when UAS-pG2 and pE1ASV were cotransfected with the GAL-VP16 and GAL-ER(EF) expression vectors (Fig. 6, lanes 9-12; Table 2).

Because the promoter of the parental vector that was used to express the estrogen and glucocorticoid receptors GAL4, GAL-VP16, and GAL-ER(EF) contains the SV40 enhancer (Breathnach and Harris 1983), it was important to check that the inhibition by the E1A products did not result from decreases in the amounts of trans-activators synthesized in the transfected HeLa cells. This was done in the case of the estrogen receptor (Fig. 7). The amount of receptor synthesized in the pE1ASV cotransfected cells was not decreased; in fact, we found that it was increased, using either a gel retardation assay with a ${ }^{32} \mathrm{P}$ labeled ERE (Fig. 7A, cf. + ElA and -ElA) or Western immunoblotting (Fig. 7B, in which the upper band was nonspecific). The reason for this unexpected, but reproducible, increase in ER protein is unknown.

The magnitude of the E1A repression is not affected by treatment with the tumor promoter TPA

Phorbol esters, such as TPA, which activate the protein kinase C signal pathway (Nishizuka 1988), are known to stimulate the activity of a number of (but not all; see Table 1) proto-enhancers, notably in HeLa cells. Thus, the activity of the TC-II and $\mathrm{H}-2 \mathrm{~K}^{\mathrm{b}}$ enhansons is stimulated $\sim 2$-fold and $\sim 14$-fold, respectively (see Kanno et al. 1989), whereas that of the Py-AP1 enhanson (Imler et al. 1988) is increased $\sim 13$-fold and that of the MTIIAAP1 enhanson (Imagawa et al. 1987) is stimulated $\sim 4$ fold (Table 1). In all four cases, the magnitude of the E1A repression was not markedly affected by the TPA treatment. Moreover, it was apparently independent of the extent of the stimulation brought about by TPA (Table 1). In contrast to the report of Chiu et al. (1987), we did not find stimulation of the activity of the SV40 P element by TPA. The reason for this discrepancy is not known, but we note that in our case, the polymerized $P$ element is flanked on its $5^{\prime}$ side by the natural SV40 bases.

\section{Enhancer repression does not require the acidic region of $E 1 A$ proteins}

Some transcriptional trans-activators, such as GAL4 and VP16, contain an acidic activating domain (for review, see Ptashne 1988). Moreover, it has been shown that the very potent acidic trans-activator GAL-VP16 (see above) can efficiently inhibit transcription from pro-

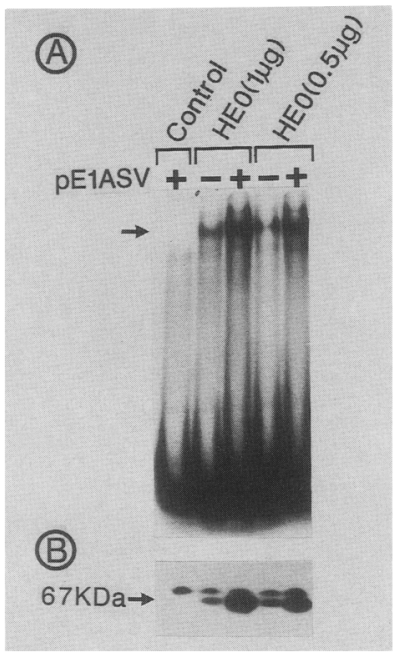

Figure 7. Gel retardation assay $(A)$ and immunoblotting assay $(B)$ of the ER in HeLa whole cell extracts. HeLa cells were cotransfected with ERE-pG2 $(2 \mu \mathrm{g})$ and HEO (the vector expressing the estrogen receptor; 0.5 or $1 \mu \mathrm{g})$, in the absence $(-1$ or in the presence $(+)$ of $\mathrm{pE} 1 \mathrm{ASV}(1 \mu \mathrm{g})$, as indicated. Whole cell extracts were prepared as described in Materials and methods and subjected to gel retardation $(A)$ or immunoblotting $|B|$. In $A$, the arrow indicates the localization of the band corresponding to the specific receptor complex. The control corresponds to an extract from HeLa cells cotransfected with ERE-pG2 and pE1ASV recombinants but not HEO. In $B$, proteins from whole cell extracts $(2 \mu \mathrm{g})$ were resolved on a $10 \%$ polyacrylamide gel in the presence of SDS, electrotransferred to a nitrocellulose filter, and probed with an ER (F domain)-specific monoclonal antibody (Metzger et al. 1988). Filters were then incubated with rabbit anti-mouse antibodies, and the bands were visualized with ${ }^{125}$ I-labeled protein A (Metzger et al. 1988). The arrow indicates the 67-kD ER. Note that the upper band, which is nonspecific, is present in the control lane.

moters lacking the cognate GAL4-binding sites (Gill and Ptashne 1988; Ptashne 1988). This phenomenon, called 'squelching', was reported (Gill and Ptashne 1988) to depend on the 'strength' of the acidic activating domain. Could such squelching account for repression by E1A? To test this hypothesis, we first studied the effect of GAL-VP16 expression on the activity of the SV40 enhancer and of its different enhansons using the pG2 series (Fig. 4B; Table 2), which does not carry a GAL4binding site. It is clear that transfection into HeLa cells of $2 \mu \mathrm{g}$ of a vector expressing GAL-VP16, together with reporter genes containing the whole SV40 enhancer (pG2B) or tetramers (in pG2) of either the GT-IIC + GT$\mathrm{I}$, the TC-II, or the Sph (II $+\mathrm{I})$ proto-enhancers, resulted in repression of enhancer activity in all cases. Note here that the activity of the enhancerless SV40 promoter present in the pA56 reference recombinants (EES signal) was also reproducibly repressed by GAL-VP16, whereas no inhibition was seen for the globin promoter present in pG2 (Fig. 4B; data not shown).

The above results prompted us to investigate whether the acidic regions that are present between amino acids 126 and 148 of the $289 \mathrm{R}$ protein and amino acids 126 
and 138 of the 243R protein (Fig. 1) could be responsible for the ElA repression of enhancer activity. We first constructed an expression vector, GAL-E1A(AD), in which the GAL4|1-147)DBD is fused with the ClaISmaI fragment of the E1A gene (Fig. 1) which encodes the E1A amino acids 122-151. GAL-E1A(AD) did not repress the activity of the various SV40 enhansons in cotransfection experiments (Fig. 4A, lanes 4, 12, 16, 20, and 24; Fig. 5, lane 5), nor that of the ER and GR (Fig. 5, lanes 17 and 23). However, GAL-E1A(AD) could stimulate the expression of a reporter recombinant containing GAL4-binding sites (17M2-GLOB-CAT; see N. Webster et al. 1988b), but to a lesser extent than that achieved with GAL4 (approximately three to fourfold; data not shown).

To confirm that the acidic amino acid stretch present in the E1A proteins was not responsible for the enhancer repression, we constructed the vector pE1ASVA, in which the ClaI-SmaI segment present in pE1ASV was deleted, resulting in the expression of a single ElA protein similar to the $289 \mathrm{R}$ protein, but deleted for amino acids $123-150$, and therefore lacking the acidic amino acid stretch present in this region. The protein encoded in pE1ASV $\Delta$ repressed the activity of the whole SV40 enhancer, its different enhansons, and the ER and GR as efficiently as pE1ASV (Fig. 4A, lanes 3, 11, 15, 19, and 23; Fig. 5, lanes 4, 16, and 22). Thus, the acidic region of the ElA proteins does not appear to be essential for enhancer repression. However, it is important for E1A trans-activation, as suggested previously by Lillie and Green (1989). Indeed, pE1ASV $\Delta$ could not trans-activate the Ad2 E2 promoter under conditions where efficient trans-activation was readily achieved with pE1ASV (Fig. 8 , cf. lanes 3 and 4 ).

\section{Discussion}

We have addressed the question of whether the repression of the SV40 enhancer by the E1A gene products can be ascribed specifically to one of its constituent protoenhancers whose synergistic effects generate the overall enhancer activity. By studying enhancer elements separately, we demonstrate that they can all be repressed. The E1A gene products inhibit the activity of class A (GT-IIC, Sph-II, Sph-I), class B (GT-I), and class C (TC-II, octamer) enhansons (Tables 1-3; Figs. 3 and 4). Furthermore, our study clearly shows that the inhibitory effect of the ElA gene products on enhancer activity is not limited to the SV40 enhansons. The activities of the polyomavirus and human metallothionein enhansons, which bind the AP-1 factor, and the activity of the MHC class I gene enhanson $\mathrm{H}-2 \mathrm{~K}^{\mathrm{b}}$, which binds the TC-IIB/ $\mathrm{KBF} 1 / \mathrm{H} 2 \mathrm{TF} 1$ protein (Kimura et al. 1986; Baldwin and Sharp 1987, 1988; Macchi et al. 1989, and references therein), are also repressed by the E1A gene products. Moveover, our results demonstrate that repression by the ElA gene products is not restricted to enhancers composed of multiple proto-enhancers (e.g., those of SV40, polyomavirus, immunoglobulin, and insulin genes; for references, see introductory section) but can also affect trans-activators binding to class $\mathrm{D}$ enhansons that possess enhancer activity independently (Fromental et al. 1988), for example, the glucocorticoid receptor and the estrogen receptor (Fig. 5; Table 2).

Our results suggest that the E1A gene products could repress all enhancer-binding trans-activator proteins. Thus, the activity of the yeast enhancer factor GAL4, when expressed in HeLa cells, as well as the activity of the chimeric trans-activators GAL-VP16 and GAL$\mathrm{ER}(\mathrm{EF})$, are repressed by E1A. Interestingly, although both GAL4 and GAL-VP16 trans-activating domains contain acidic amino acid stretches (Kakidani and Ptashne 1988; Sadowski et al. 1988, and references therein; N. Webster et al. 1988a), the estrogen receptor trans-activating domain present in GAL-ER(EF) is not acidic and exhibits activating properties different from those of GAL4 or GAL-VP16 (Tora et al. 1989; Webster et al. 1989).

Our results indicate clearly that the inhibition of the activity of the ER by the E1A gene products is not attributable to a decrease in the amount of receptor synthesized from the cotransfected ER expression vector HEO. This is an important control result, because the promoter of the parental expression vector that was also used to express the glucocorticoid receptor, GAL4, GAL-VP16, and GAL-ER(EF), contains the SV40 enhancer, which may have resulted in decreases in the amounts of the trans-activators synthesized in HeLa cells cotransfected with the E1A expression vector. We cannot, however, perform similar control experiments in the case of the enhancer factors that mediate the activity of the SV40, polyomavirus, metallothionein, and $\mathrm{H}-2 \mathrm{~K}^{\mathrm{b}}$ enhansons. Thus, at the present time, we cannot exclude the fact that the inhibition of the activity of these enhansons reflects a repression of the transcription of the genes that encode their cognate factors.

How the E1A gene products can repress the activity of a wide variety of enhansons is not known. The E1A proteins do not appear to bind directly to DNA /Ferguson et al. 1985; Lillie and Green 1989, and references therein), and the sequence diversity of the repressed enhansons excludes the existence of a common DNA target for repression. Similarly, it is unlikely that the E1A proteins act by interacting directly with the various trans-activating factors that mediate the activity of the different enhansons. An induced phosphorylation of some transacting factors has recently been implicated in activation of transcription by E1A (Bagchi et al. 1989; Jones and Jones 1989; Raychaudhuri et al. 1989). One may speculate that such an E1A-induced phosphorylation may result in the repression of a different set of trans-activators or possible intermediary factor(s) mediating their activity (Fromental et al. 1988; Meyer et al. 1989; Tora et al. 1989/. We note, however, that the phorbol ester (TPA)-induced activation of several enhansons, which is presumably mediated by protein kinase $\mathrm{C}_{\text {, }}$ is not repressed by the ElA gene products (Table 1). Additional examples of induction of ElA-repressed promoters by phorbol esters and growth factors have been reported recently (Offringa et al. 1988; Timmers et al. 1989). 
Alternatively, the E1A proteins may block the function of enhancer factors by binding to a protein that is necessary to mediate their activity. The repression function of the ElA gene products is present in both the 243R and 289R E1A proteins [e.g., see Borrelli et al. (1984); note that in all of the cases studied here the same repressions were observed by cotransfecting the expression vectors that encode either the 243R /vector $\mathrm{pE} 1 \mathrm{A1} 2 \mathrm{~S}$ ) or the $289 \mathrm{R}$ (vector pE1A13S) proteins (C. Rochette-Egly, unpublished data)]. However, the $289 \mathrm{R}$ protein is a much better trans-activator than the $243 \mathrm{R}$ protein (for references, see introductory section). Therefore, it is unlikely that E1A repression results from the phenomenon referred to as squelching, that is, direct competition for a transcription factor present in limiting amount by an excess of an activating domain-an acadic domain such as that present in the VP16 protein (Gill and Ptashne 1988). Interestingly, although expression of the VP16 acidic domain present in GAL-VP16 can inhibit the activity of the SV40 enhancer and enhansons (Table 2; Fig. 4B; note that the TC-II enhanson appears to be less sensitive to VP16 than to E1A inhibition), deletion of the acidic amino acid stretch, which is located across the border of domain 2 and 3 of the E1A gene products /vector pE1ASVD, in which amino acids 123-150 are deleted; see Fig. 1), does not affect E1A repression. In contrast, the protein encoded by pE1ASV $\Delta$ has lost totally its trans-activating function (Fig. 8), in agreement with previous reports demonstrating the importance of E1A-conserved region 3 in E1A-induced activation of transcription (for references, see introduction section; legend to Fig. 1; Lillie and Green 1989). That, however, the acidic region of the $289 \mathrm{R}$ protein is neither a strong activator (data not shown) nor a squelcher of its own (Fig. 4A) is indicated by the results of transfection

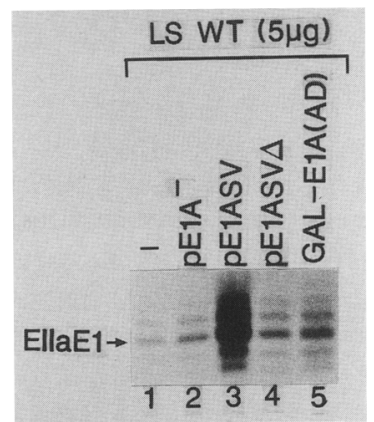

Figure 8. Stimulation of adenovinus EIIaE RNA synthesis by E1A proteins. The LS WTEIIaE recombinant (Zajchowski et al. 1985) containing the EIIaE sequences extending between -250 and +719 inserted in front of the rabbit $\beta$-globin sequence was cotransfected $(5 \mu \mathrm{g})$ with the internal control pA56 $(10 \mu \mathrm{g})$, either alone (lane 1) or together with $2 \mu \mathrm{g}$ of $\mathrm{pE}^{-1} \mathrm{~A}^{-}$(lane 2), $2 \mu \mathrm{g}$ of pE1ASV (lane 3), $2 \mu \mathrm{g}$ of pE1ASVD (lane 4), or $5 \mu \mathrm{g}$ of GAL-E1A*AD) (lane 5). Cytoplasmic RNA was analyzed by S1 nuclease mapping with the appropriate ${ }^{32} \mathrm{P}-5^{\prime}$-end-labeled single-stranded DNA probe. Specific transcripts initiated at the major EIIaE start site, EIIaEl, gave a protected fragment of 40 nucleotides. experiments with GAL-E1A|AD|, which encodes amino acids $122-151$ of E1A.

Three nuclear proteins, $105 \mathrm{~K}, 107 \mathrm{~K}$, and $300 \mathrm{~K}$, are known to bind to the ElA gene products (Egan et al. 1988, 1989; Whyte et al. 1988, 1989; Fig. 1). Two of them $(107 \mathrm{~K}$ and $\mathrm{p} 105-\mathrm{RB})$ require E1A amino acids 121-127 for binding. The present results obtained with the expression vector pElASV $\Delta$, in which the DNA sequences encoding amino acids $123-150$ have been deleted (see above), indicate clearly that the ElA-conserved region 2 is dispensable for repression, in agreement with previous reports (Kuppuswamy and Chinnadurai 1987; Velcich and Ziff 1988; Jelsma et al. 1989; Sogawa et al. 1989). Because the conserved region 3 and exon 2 are also dispensable [see the preceding references and those in Fig. 1 and our unpublished data (C. Rochette-Egly) showing that a deletion of amino acids 121-223 does not affect the extent of repression], this repression could be atributable to the binding of the E1A gene products to the cellular $300 \mathrm{~K}$ protein, thus blocking its activity. The function of the $300 \mathrm{~K}$ protein is not known. Our present results suggest that it may be an essential common intermediary factor in the pathways mediating the activation function of the various enhancer-binding factors (see also Tora et al. 1989).

\section{Materials and methods}

\section{Recombinant plasmids}

The various individual motifs of the SV40 enhancer were chemically synthesized, tandemly tetramerized, and inserted into plasmids pG1 or pG2, containing the rabbit $\beta$-globin gene and its promoter region at positions -109 and -425 , respectively, as described previously (Fromental et al. 1988; Kanno et al. 1989). The estrogen reporter gene ERE-pG2 was constructed by inserting in $\mathrm{pG} 2$ the synthetic oligonucleotide $5^{\prime}$-TCGAGCAAAGTCAGGTCACAGTGACCTGATCAAAT-3', flanked by $X h o I$ and $X b a I$ restriction enzymes sites in $5^{\prime}$ and $3^{\prime}$, respectively. The glucocorticoid reporter gene GRE-pG2 was constructed by inserting the $\mathrm{XbaI}-\mathrm{SacI}$ fragment of the PTG plasmid (Meyer et al. 1989) into the XbaI-SacI site of the polylinker of $\mathrm{pG} 2$. The activation vectors $\mathrm{HEO}$ and HGO (corresponding to the eukaryotic expression vector pKCR2 expressing the human estrogen and glucocorticoid receptors, respectively) have been described previously (Breathnach and Harris 1983; Green et al. 1986; Kumar et al. 1987). The reporter gene UASpG2 and the GAL4 and GAL-ER(EF) expression vectors have been described (N. Webster et al. 1988a,b), as well as the GALVP16 expression vector (Tora et al. 1989).

The recombinant plasmids $\mathrm{pE} 1 \mathrm{ASV}$ and $\mathrm{pE} 1 \mathrm{~A}^{-}$contained the entire ElA transcription unit (including the enhancer sequences) and only the E1A promoter region (Borrelli et al. 1984), respectively. pE1ASV $\Delta$ was constructed by excision of the ClaI-SmaI fragment (between nucleotides 916 and 1006) from the pE1ASV plasmid and religation by inserting a synthetic ClaI linker containing a XhoI site $\left(5^{\prime}\right.$-CGATCTCGAG-3'). GAL4-ElA(AD) was constructed first by cloning a synthetic ClaI-SmaI linker (5'-CGCTTCCCATCGATCTCTCCCGGGT-3'\} downstream of GAL4(1-147) between the ClaI-XhoI sites of pG4Mpoly (S. Green et al. 1988; Webster et al. 1989/ and then inserting the ClaI-SmaI fragment of the pE1ASV plasmid. 


\section{Cell lines}

HeLa cells were grown as described (Zenke et al. 1986). MPC11, LMTK - and F9 cells were grown in Dulbecco's modified Eagle minimum essential medium (GIBCO), containing $10 \%$ fetal calf serum and 500 units penicillin, $400 \mu \mathrm{g}$ gentamycin, and $100 \mu \mathrm{g}$ streptomycin per milliliter. F9(D) cells were obtained by treatment of $\mathrm{F} 9(\mathrm{ND})$ cells with retinoic acid $(0.1 \mu \mathrm{M})$ for 4 days before transfection (Nomiyama et al. 1987). TPA treatments after transfection were performed essentially as described by Imagawa et al. (1987).

\section{DNA transfection and quantitative S1 nuclease analysis}

HeLa, LMTK- ${ }^{-}$F9, and MPC11 cells were seeded and transfected as described by Fromental et al. (1988) and by Kanno et al. (1989). Calcium-phosphate-mediated transfections of all cell lines included the reference plasmid pA56 (Zenke et al. 1986; see Results|, the appropriate derivatives of pG1 or pG2, pE1ASV, and plasmid carrier DNA to adjust the total quantity to $17 \mu \mathrm{g} / 9-\mathrm{cm}$ dish.

Cytoplasmic RNA was isolated after lysing the cells with $0.5 \%$ NP-40 (Groudine et al. 1981), and $20 \mu$ g RA was hybridized overnight at $68^{\circ} \mathrm{C}$ with an excess of single-stranded ${ }^{32} \mathrm{P}-5^{\prime}$. end-labeled probe (Zenke et al. 1986) in $10 \mathrm{mM}$ PIPES (pH 6.5) and $400 \mathrm{~mm} \mathrm{NaCl}$. After a $2-\mathrm{hr} \mathrm{S1}$ nuclease digestion at $25^{\circ} \mathrm{C}$ (200 U/64 $\mu \mathrm{g}$ of RNA), the protected fragments were analyzed by electrophoresis on an $8 \%$ denaturing polyacrylamide gel. Different exposures of the autoradiographs were densitometrically scanned. In all cases, the results corresponded to the average values obtained from at least three independent transfection experiments, using at least two different plasmid preparations.

\section{Gel retardation assay for binding of ER to its ERE}

Transfected cells were washed with chilled PBS, collected, and lysed by three successive freezings (at $-80^{\circ} \mathrm{C}$ ) and thawings in $20 \mathrm{mM}$ Tris- $\mathrm{HCl}$ ( $\mathrm{pH} 9.9$ ), 25\% glycerol, $0.1 \mathrm{mM}$ EDTA, and 400 $\mathrm{mM} \mathrm{KCl}$ (Kumar and Chambon 1988). After centrifugation at $8000 \mathrm{~g}$ for $20 \mathrm{~min}$ at $4^{\circ} \mathrm{C}$, the whole-cell extract (WCE) supernatant was collected and protein concentration determined by the Bradford assay (Bradford 1976). The supernatants were aliquoted, frozen in liquid nitrogen, and stored at $-80^{\circ} \mathrm{C}$.

For gel retardation assay, aliquots of proteins $(5 \mu \mathrm{g})$ were mixed with an appropriate amount of poly[d(I-C)] (usually $5 \mu \mathrm{g}$ ) and incubated in a $20-\mu \mathrm{l}$ reaction volume containing $15 \mathrm{~mm}$ HEPES (pH 7.9), $0.4 \mathrm{~mm}$ DTT, $0.2 \mathrm{~mm}$ EDTA, $80 \mathrm{~mm} \mathrm{KCl}$, and $4 \%$ glycerol for $15 \mathrm{~min}$ at $0^{\circ} \mathrm{C}$. The binding reaction, initiated by adding a ${ }^{32} \mathrm{P}-5^{\prime}$-end-labeled synthetic oligonucleotide probe $\left(4 \times 10^{4} \mathrm{cpm}_{\text {; }}\right.$ probe $\mathrm{A}$ in Kumar and Chambon 1988), was in. cubated at $25^{\circ} \mathrm{C}$ for $15 \mathrm{~min}$. DNA-protein complexes were then separated at $20^{\circ} \mathrm{C}$ in a $5 \%$ nondenaturing polyacrylamide gel containing $6.6 \mathrm{~mm}$ Tris- $\mathrm{HCl}(\mathrm{pH} 7.5), 3.3 \mathrm{~mm}$ sodium acetate, and $1 \mathrm{mM}$ EDTA at $25 \mathrm{~mA}$ with buffer recirculation.

\section{Acknowledgments}

We are grateful to H. Boeuf, M. Kanno, and B. Wasylyk for gifts of recombinants and to $D$. Metzger for the estrogen receptor (F domain) monoclonal antibodies. We thank E. Scheer for technical assistance. We also thank C. Kédinger and I. Davidson for critically reading the manuscript and $M$. Kanno for helpful discussions. We thank the cell culture group for maintaining and providing cells, C. Werlé and B. Boulay for illustrations, and the secretarial staff for assembling the manuscript. This work was supported by grants from the Centre National de la Recherche Scientifique, the Institut de la Santé et de la Recherche Médicale, the Association pour la Recherche sur la Cancer, the Foundation pour la Recherche Médicale, and the Ligue Nationale Française contre le Cancer. C.F. was supported by a fellowship from the Fondation pour la Recherche Médicale.

\section{References}

Angel, P., M. Imagawa, R. Chiu, B. Stein, R.J. Imbra, H.J. Rahmsdorf, C. Jonat, P. Herrlich, and M. Karin. 1987. Phorbol ester-inducible genes contain a common cis element recognized by a TPA-modulated trans-acting factor. Cell 49: 729-739.

Bagchi, S., P. Raychaudhuri, and J.R. Nevins. 1989. Phosphorylation-dependent activation of the adenovirus-inducible E2F transcription factor in a cell-free system. Proc. Natl. Acad. Sci. 86: 4352-4356.

Baldwin, A.S. Jr. and P.A. Sharp. 1987. Binding of a nuclear factor to a regulatory sequence in the promoter of the mouse $\mathrm{H}-2 \mathrm{~K}^{\mathrm{b}}$ class I major histocompatibility gene. Mol. Cell. Biol. 7: 305-313.

. 1988. Two transcription factors, NF- $\mathrm{BB}$ and H2TF1, interact with a single regulatory sequence in the class I major histocompatibility complex promoter. Proc. Natl. Acad. Sci. 85: 723-727.

Berk, A.J. 1986a. Adenovirus promoters and ElA transactivation. Annu. Rev. Genet. 20: 45-79.

Berk, A.J. 1986b. Functions of adenovirus E1A. Cancer Surv. 5: 367-389.

Borrelli, E., R. Hen, and P. Chambon. 1984. Adenovirus-2 E1A products repress enhancer-induced stimulation of transcription. Nature 312: 608-612.

Bradford, M.M. 1976. A rapid and sensitive method for the quantitation of microgram quantities of protein utilizing the principle of protein-dye binding. Anal. Biochem. 72: 248254.

Breathnach, R. and B.A. Harris. 1983. Plasmids for the cloning and expression of full-length double stranded cDNAs under control of the SV40 early or late gene promoter. Nucleic Acids Res. 11: 7119-7136.

Chiu, R., M. Imagawa, R.J. Imbra, J.R. Bockoven, and M. Karin. 1987. Multiple cis- and trans-acting elements mediate the transcriptional response to phorbol esters. Nature 329: 648651.

Davidson, I., C. Fromental, P. Augereau, A. Wildeman, M. Zenke, and P. Chambon. 1986. Cell-type specific protein binding to the enhancer of simian virus 40 in nuclear extracts. Nature 323: 544-548.

Davidson, I., J.H. Xiao, R. Rosales, A. Staub, and P. Chambon. 1988. The HeLa cell protein TEF-1 binds specifically and cooperatively to two SV40 enhancer motifs of unrelated sequence. Cell 54: 931-942.

Egan, C., T.N. Jelsma, J.A. Howe, S.T. Bayley, B. Ferguson, and P.E. Branton. 1988. Mapping of cellular protein-binding sites on the products of early-region $1 \mathrm{~A}$ of human adenovirus type 5. Mol. Cell. Biol. 8: 3955-3959.

Egan, C., S.T. Bayley, and P.E. Branton. 1989. Binding of the $\mathrm{Rbl}$ protein to ElA products is required for adenovirus transformation. Oncogene 4: 383-388.

Fahnestock, M.L. and J.B. Lewis. 1989. Genetic dissection of the transactivating domain of the E1A $289 \mathrm{R}$ protein of adenovirus type 2. J. Virol. 63: 1495-1504.

Ferguson, B., B. Krippl, O. Andrisani, N. Jones, H. Westphal, and M. Rosenberg. 1985. E1A 13 S and 12S mRNA products made in Escherichia coli both function as nucleus-localized 
transcription activators but do not directly bind DNA. Mol. Cell. Biol. 5: 2653-2661.

Fletcher, C., N. Heintz, and R.G. Roeder. 1987. Purification and characterization of OTF-1, a transcription factor regulating cell cycle expression of a human histone $\mathrm{H} 2 \mathrm{~b}$ gene. Cell 51: $773-781$.

Friedman, D.J. and R.P. Ricciardi. 1988. Adenovirus type 12 E1A gene represses accumulation of MHC class I mRNAs at the level of transcription. Virology 165: 303-305.

Fromental, C. 1989. Etude structurale et fonctionnelle de la séquence "enhancer" du virus simien 40 (SV40). Ph.D. Thesis, University Louis Pasteur, Strasbourg.

Fromental, C. 1989. Ph.D. Thesis, University Louis Pasteur, Strasbourg.

Gerster, T., P. Matthias, M. Thali, J. Jiricny, and W. Schaffner. 1987. Cell type specificity elements of the immunoglobulin heavy chain gene enhancer. EMBO I. 6: 1323-1330.

Gill, G. and M. Ptashne. 1988. Negative effect of the transcription activator GAL4. Nature 334: 721-724.

Graham, F.L. 1984. Transformation by and oncogenicity of human adenoviruses. In the adenoviruses (ed. H. Ginsberg), pp. 339-398. Plenum Press. New York.

Grand, R.J.A. 1987. The structure and functions of the adenovirus early region 1 proteins. Biochem. I. 241: 25-38.

Green, M., P.M. Loewenstein, R. Pusztai, and J.S. Symington. 1988. An adenovirus E1A protein domain activates transcription in vivo and in vitro in the absence of protein synthesis. Cell 53: 921-926.

Green, S., P. Walter, V. Kumar, A. Krust, J.M. Bornert, P. Argos, and P. Chambon. 1986. Human oestrogen receptor cDNA: Sequence, expression and homology to v-erb-A. Nature 320: 134-139.

Green, S., and P. Chambon. 1988. Nuclear receptors enhance our understanding of transcription regulation. Trends Genet. 4: 309-314.

Green, S., I. Issemann, and E. Scheer. 1988. A versatile in vivo and in vitro eukaryotic expression vector for protein engineering. Nucleic Acids Res. 16: 369-370.

Groudine, M., M. Peretz, and H. Weintraub. 1981. Transcriptional regulation of hemoglobin switching in chicken embryos. Mol. Cell. Biol. 1: 281-288.

Guarente, L. 1988. UASs and enhancers: Common mechanism of transcriptional activation in yeast and mammals. Cell 52: 303-305.

Hardy, S., D.A. Engel, and T. Shenk. 1989. An adenovirus early region 4 gene product is required for induction of the infection-specific form of cellular E2F activity. Genes Dev. 3: $1062-1074$.

Hen, R., E. Borrelli, and P. Chambon. 1985. Repression of the immunoglobulin heavy chain enhancer by the adenovirus- 2 E1A products. Nature 321: 249-251.

Herr, W. and J. Clarke. 1986. The SV40 enhancer is composed of multiple functional elements that can compensate for one another. Cell 45: 461-470.

Hoeffler, W.K., R. Kovelman, and R.G. Roeder. 1988. Activation of transcription factor IIIC by the adenovirus E1A protein. Cell 53: 907-920.

Imagawa, M., R. Chiu, and M. Karin. 1987. Transcription factor AP-2 mediates induction by two different signal transduction pathways: Protein kinase C and cAMP. Cell 51: 251260.

Imler, J.L., C. Schatz, C. Wasylyk, B. Chatton, and B. Wasylyk. 1988. A Harvey-ras responsive transcription element is also responsive to a tumour-promoter and to serum. Nature 332: $275-278$.

Jansen-Durr, P., H. Boeuf, and C. Kédinger. 1989. Cooperative binding of two E2F molecules to an EIa-responsive promoter is triggered by the adenovirus EIa, but not by a cellular EIalike activity. EMBO I. 8: 3365-3370.

Jelsma, T.N., J.A. Howe, C.M. Evelegh, N.F. Cunniff, M.H. Skiadopoulos, M.R. Floroff, J.E. Denman, and S.T. Bayley. 1988. Use of deletion and point mutants spanning the coding region of the adenovirus $5 \mathrm{E} 1 \mathrm{~A}$ gene to define a domain that is essential for transcriptional activation. $V i$ rology 163: 494-502.

Jelsma, T.N., J.A. Howe, J.S. Mymryk, C.M. Evelegh, N.F.A. Cunniff, and S.T. Bayley. 1989. Sequences in E1A proteins of human adenovirus 5 required for cell transformation, repression of a transcriptional enhancer, and induction of proliferating cell nuclear antigen. Virology 171: 120-130.

Jones, N.C., P.W. Rigby, and E.B. Ziff. 1988. Transacting protein factors and the regulation of eukaryotic transcription: Lessons from studies on DNA tumor viruses. Genes Dev. 2: $267-281$.

Jones, R.H. and N.C. Jones. 1989. Mammalian cAMP-responsive element can activate transcription in yeast and binds a yeast factor(s) that resembles the mammalian transcription factor ATF. Proc. Nat1. Acad. Sci. 86: 2176-2180.

Kakidani, H. and M. Ptashne. 1988. GAL4 activates gene expression in mammalian cells. Cell 52: 161-167.

Kanno, M., C. Fromental, A. Staub, F. Ruffenach, I. Davidson, and P. Chambon. 1989. The SV40 TC-II $(\kappa B)$ and the related $\mathrm{H}-2 \mathrm{~K}^{\mathrm{b}}$ enhansons exhibit different cell-type specific and inducible proto-enhancer activities, but the SV40 core sequence and the AP-2 binding site have no enhanson properties. $E M B O J$. (in press).

Kimura, A., A. Israel. O. Le Bail, and P. Kourilsy. 1986. Detailed analysis of the mouse $\mathrm{H}-2 \mathrm{~K}^{\mathrm{b}}$ promoter: Enhancer-like sequences and their role in regulation of class I gene expression. Cell 44: 261-272.

Kumar, V., S. Green, G. Stack, M. Berry, J.-R. Jin, and P. Chambon. 1987. Functional domains of the human estrogen receptor. Cell 51: 941-951.

Kumar, V. and P. Chambon. 1988. The estrogen receptor binds tightly to its responsive element as a ligand-induced homodimer. Cell 55: 145-156.

Kuppuswamy, M.N. and G. Chinnadurai. 1987. Relationship between the transforming and transcriptional regulatory functions of adenovirus 2 E1a oncogene. Virology 159: 31 38.

Lee, W., A. Haslinger, M. Karin, and R. Tjian. 1987. Two factors that bind and activate the human metallothionein IIA gene in vitro also interact with the SV40 promoter and enhancer regions. Nature 325: 368-372.

Lee, K.A.W., T.Y. Hai, L. Sivaraman, B. Thimmappaya, H.C. Hurst, N.C. Jones, and M.R. Green. 1987. A cellular protein, activating transcription factor, activates transcription of multiple E1A-inducible adenovirus early promoter. Proc. Natl. Acad. Sci. 84: 8355-8359.

Leff, T., R. Elkaim, C.R. Goding, P. Jalinot, P. Sassone-Corsi, M. Perricaudet, C. Kédinger, and P. Chambon. 1984. Individual products for the adenovirus $12 \mathrm{~S}$ and $13 \mathrm{~S}$ Ela mRNAs stimulate viral E11a and E111 expression at the transcriptional level. Proc. Natl. Acad. Sci. 81: 4381-4385.

Lillie, J.W., M. Green, and M.R. Green. 1986. An adenovirus Ela protein region required for transformation and transcriptional repression. Cell 46: 1043-1051.

Lillie, J.W., P.M. Loewenstein, M.R. Green, and M. Green. 1987. Functional domains of adenovirus type 5 Ela proteins. Cell 50: 1091-1100.

Lillie, J.W. and M.R. Green. 1989. Transcription activation by the adenovirus Ela protein. Nature 338: $39-44$. 
Macchi, M., J.M. Bornert, I. Davidson, M. Kanno, R. Rosales, M. Vigneron, J.H. Xiao, C. Fromental, and P. Chambon. 1989. The SV40 TC-II $(\kappa B)$ enhanson binds ubiquitous and cell type-specifically inducible nuclear proteins from lymphoid and non-lymphoid cell lines. $E M B O J$. (in press).

Meijer, I., A.G. Jochemsen, C.M. de Wit, J.L. Bos, D. Morello, and A.J. van der Eb. 1989. Adenovirus type 12 ElA down regulates expression of a transgene under control of a major histocompatibility complex class I promoter: Evidence for transcriptional control. J. Virol. 63: 4039-4042.

Metzger, D., J.H. White, and P. Chambon. 1988. The human oestrogen receptor functions in yeast. Nature 334: 31-36.

Meyer, M.E., H. Gronemeyer, B. Turcotte, M.T. Bocquel, D. Tasset, and P. Chambon. 1989. Steroid hormone receptors for factors that mediate their enhancer function. Cell 57: 433-442.

Moran, E., B. Zerler, T.M. Harrison, and M.B. Mathews. 1986. Identification of separate domains in the adenovirus ElA gene for immortalization activity and the activation of virus early genes. Mol. Cell. Biol. 6: 3470-3480.

Nishizuka, Y. 1988. The molecular heterogeneity of protein kinase $\mathrm{C}$ and its implication for cellular regulation. Nature 334: $661-665$.

Nomiyama, H., C. Fromental, J.H. Xiao, and P. Chambon. 1987. Cell-specific activity of the constituent elements of the simian virus 40 enhancer. Proc. Natl. Acad. Sci. 84: 78817885.

Offringa, R., A.M.M. Smits, A. Houwelling, J.L. Bos, and A.J. Van der Eb. 1988. Similar effects of adenovirus ElA and glucocorticoid hormones on the expression of the metalloprotease stromelysin. Nucleic Acids Res. 16: 10973-10984.

Ondek, B., A. Shepard, and W. Herr. 1987. Discrete elements within the SV40 enhancer region display different cell-specific enhancer activities. EMBO I. 6: 1017-1025.

Ondek, B., L. Gloss, and Herr, W. 1988. The SV40 enhancer contains two distinct levels of organization. Nature 333: $40-45$.

Perricaudet, M., G. Akusjarvi, A. Virtanen, and U. Pettersson. 1979. Structure of two spliced mRNAs from the transforming region of human subgroup $\mathrm{C}$ adenoviruses. Nature 281: 694-696.

Pettersson, M. and W. Schaffner. 1987. A purine-rich DNA sequence motif present in SV40 and lymphotropic papovavirus binds a lymphoid-specific factor and contributes to enhancer activity in lymphoid cells. Genes Dev. 1: 962-972.

Ptashne, M. 1988. How eukaryotic transcriptional activators work. Nature 335: 683-689.

Raychaudhuri, P., S. Bagchi, and J.R. Nevins. 1989. DNAbinding activity of the adenovirus-induced E4F transcription factor is regulated by phosphorylation. Genes Dev.3: 620627.

Sadowski, I., J. Ma, S. Triezenberg, and M. Ptashne. 1988. GAL4-VP16 is an unusually potent transcriptional activator. Nature 335: 563-564.

Sassone-Corsi, P., R. Hen, E. Borrelli, T. Leff, and P. Chambon. 1983. Far upstream sequences are required for efficient transcription from the adenovirus-2 E1A transcription unit. $\mathrm{Nu}$ cleic Acids Res. 11:8735-8745.

Sassone-Corsi, P. 1985. Pleiotropic action of the adenovirus E1A proteins. Trends Genet. 1: 98.

Schirm, S., J. Jiricny, and W. Schaffner. 1987. The SV40 enhancer can be dissected into multiple segments, each with a different cell type specificity. Genes Dev. 1: 65-74.

Schneider, J.F., F. Fisher, C.R. Goding, and N.C. Jones. 1987. Mutational analysis of the adenovirus E1A gene: The role of transcriptional regulation in transformation. EMBO $J$.
6: 2053-2060.

Sen, R. and D. Baltimore. 1986. Multiple nuclear factors interact with the immunoglobulin enhancer sequences. Cell 46: 705-716.

Sogawa, K., H. Handa, A. Fujisawa-Sehara, T. Hiromasa, M. Yamane, and Y. Fujii-Kuriyama. 1989. Repression of cytochrome P-450c gene expression by cotransfection with adenovirus E1A DNA. Eur. J. Biochem. 181: 539-544.

Stein, R.W. and E.B. Ziff. 1987. Repression of insulin gene expression by adenovirus type 5 ElA proteins. Mol. Cell. Biol. 7: 1164-1170.

Struhl, K. 1987. Promoters, activator proteins, and the mechanism of transcriptional initiation in yeast. Cell 49: 295297.

Tanaka, M., U. Grossniklaus, W. Herr, and N. Hernandez. 1988. Activation of the U2 snRNA promoter by the octamer motif defines a new class of RNA polymerase II enhancer elements. Genes Dev. 2: 1764-1778.

Timmers, H.T.M., D. De Wit, J.L. Bos, and A.J. Van der Eb. 1988. E1A products of adenoviruses reduce the expression of cellular proliferation-associated genes. Oncogene Res. 3: $67-76$.

Timmers, H.T.M., H. Van Dam, G.J. Pronk, J.L. Bos, and A.J. Van der Eb. 1989. Adenovirus E1A represses transcription of the cellular JE gene. J. Virol. 63: 1470-1473.

Tora, L., J. White, C. Brou, D. Tasset, N. Webster, E. Scheer, and P. Chambon. 1989. The human estrogen receptor contains two independent and different transcriptional activation functions whose properties are distinct from those of acidic activators. Cell 59: 477-487.

Vaessen, R.T.M., D. De Wit, J.L. Bos, and A.J. Van der Eb. 1987. Post-transcriptional nuclear control of class I MHC mRNA expression in adenovirus12-transformed cells. Science 235: 1486-1488.

Velcich, A. and E. Ziff. 1985. Adenovirus Ela proteins repress transcription from the SV40 early promoter. Cell 40: 705716.

Velcich, A., F.G. Kern, C. Basilico, and E.B. Ziff. 1986. Adenovirus Ela proteins repress expression from polyomavirus early and late promoters. Mol. Cell. Biol. 6: 4019-4025.

Velcich, A. and E.B. Ziff. 1988. Adenovirus E1A ras cooperation activity is separate from its positive and negative transcription regulatory functions. Mol. Cell. Biol. 8: 2177-2183.

Webster, K.A., G.E.O.Muscat, and L. Kedes. 1988. Adenovirus E1A products suppress myogenic differentiation and inhibit transcription from muscle-specific promoters. Nature 322: 553-557.

Webster, N., J.R. Jin, S. Green, M. Hollis, and P. Chambon. 1988a. The yeast $\mathrm{UAS}_{\mathrm{G}}$ is a transcriptional enhancer in human HeLa cells in the presence of the GAL4 trans-activator. Cell 52: 169-178.

Webster, N., S. Green, J.R. Jin, and P. Chambon. 1988b. The hormone-binding domains of the estrogen and glucocorticoid receptors contain an inducible transcription activation function. Cell 54: 199-207.

Webster, N., S. Green, D, Tasset, M. Ponglikitmongkol, and P. Chambon. 1989. The transcriptional activation function located in the hormone-binding domain of the human oestrogen receptor is not encoded in a single exon. EMBO J. 8: 1441-1446.

Whyte, P., K.J. Buchkovich, J.M. Horowitz, S.H. Friend, M. Raybuck, R.A. Weinberg, and E. Harlow. 1988. Association between an oncogene and an anti-oncogene: The adenovirus E1A proteins bind to the retinoblastoma gene product. $\mathrm{Na}$ ture 334: 124-129.

Whyte, P., N.M. Williamson, and E. Harlow. 1989. Cellular 
Rochette-Egly et al.

targets for transformation by the adenovirus ElA proteins. Cell 56: 67-75.

Xiao, J.H. I. Davidson, M. Macchi, R. Rosales, M. Vigneron, A Staub, and P. Chambon. 1987a. In vitro binding of several cell-specific and ubiquitous nuclear proteins to the GT-I motif of the SV40 enhancer. Genes Dev. 1: 794-807.

Xiao, J.H., I. Davidson, D. Ferrandon, R. Rosales, M. Vigneron, M. Macchi, F. Ruffenach, and P. Chambon. 1987b. One cellspecific and three ubiquitous nuclear proteins bind in vitro to overlapping motifs in the domain B1 of the SV40 enhancer. EMBO J. 6: 3005-3013.

Young, K.S., R. Weigel, S. Hiebert, and J.R. Nevins. 1989. Adenovirus ElA-mediated negative control of genes activated during F9 differentiation. Mol. Cell. Biol. 9: 3109-3113.

Zajchowski, D.A., H. Boeuf, and C. Kédinger. 1985. The adenovirus- 2 early EIIA transcription unit possesses two overlapping promoters with different sequence requirements for EIA dependent stimulation. EMBO I. 4: 1293-1300.

Zenke, M., T. Grundström, H. Matthes, M. Wintzerith, C. Schatz, A. Wildeman, and P. Chambon. 1986. Multiple sequence motifs are involved in SV40 enhancer function. EMBO I. 5: 387-397. 


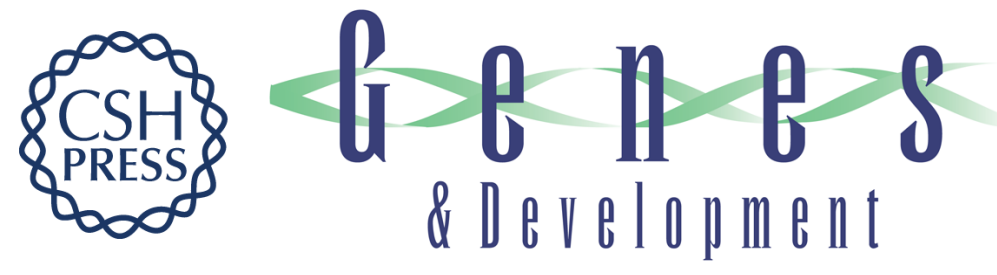

\section{General repression of enhanson activity by the adenovirus-2 E1A proteins.}

C Rochette-Egly, C Fromental and P Chambon

Genes Dev. 1990, 4:

Access the most recent version at doi:10.1101/gad.4.1.137

References This article cites 90 articles, 27 of which can be accessed free at:

http://genesdev.cshlp.org/content/4/1/137.full.html\#ref-list-1

\section{License}

Email Alerting

Service

Receive free email alerts when new articles cite this article - sign up in the box at the top right corner of the article or click here.

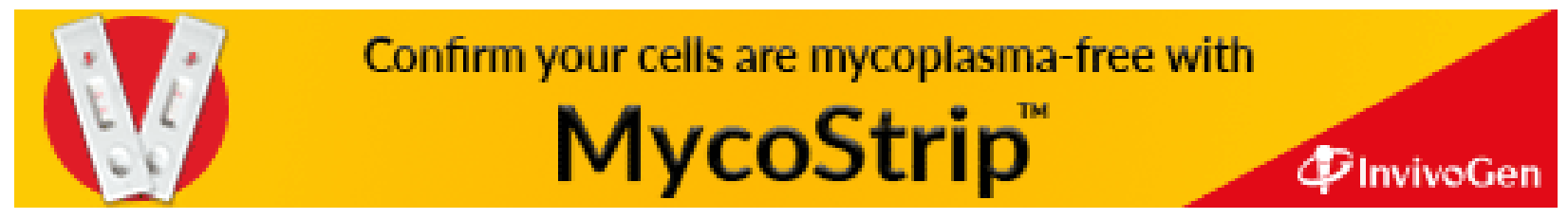

